\title{
PENGARUH COVID-19 TERHADAP HARGA SAHAM DI INDONESIA TAHUN 2019-2020 Studi Kasus di Indonesia
}

\author{
(The Effect of Covid-19 on Stock Prices in Indonesia 2019-2020)
}

\section{Shaula Andreinna A ${ }^{1}$, Maulidya Ayu $\mathrm{P}^{2}$, Umniyyatul Ula ${ }^{3}$, Silva Rizqi ${ }^{4}$, Farhatun Nissa5, Hendro Cahyo ${ }^{6}$ )}

Universitas Islam Indonesia ${ }^{1}$

Universitas Islam Indonesia ${ }^{2}$

Universitas Islam Indonesia ${ }^{3}$

Universitas Islam Indonesia ${ }^{4}$

Universitas Islam Indonesia ${ }^{5}$

Universitas Islam Indonesia ${ }^{6}$

Jl. Kaliurang KM 14,5, Sleman, Yogyakarta 55584

E-mail: 17611001@students.uii.ac.id

\begin{abstract}
ABSTRAK
Saham adalah salah satu instrumen pasar modal yang dapat didefiniskan sebagai tanda penyertaan modal seorang atau sepihak (badan usaha) dalam suatu perusahaan atau perseroan terbatas. Faktor yang terjadi sekarang dalam sektor pasar saham yaitu adanya dampak dari virus corona terhadap indeks harga saham dan arus dana asing ke pasar saham. Maka sangat perlu untuk dilakukan analisis pengaruh dampak virus pandemi corona terhadap sektor pasar saham untuk melihat bagaimana perbandingan pergerakan IHSG di Indonesia sebelum terjadi pandemi dan pada saat terjadi pandemi Covid-19. Metode yang digunakan untuk analisis perbandingan adalah Simple Moving Average dan Weighted Moving Average. Dari hasil analisis deskriptif pada data IHSG di Indonesia didapatkan rata-rata pada variabel Adj Close sebelum terjadi pandemi adalah sebesar 6353.71, dengan nilai minimum sebesar 5907.12 dan nilai maksimum sebesar 6525.36 . Nilai rata-rata pada saat terjadi pandemi adalah sebesar 5143.929, dengan nilai minimum sebesar 3937.632 dan nilai maksimum sebesar 6325.406. Hasil perbandingan menunjukkan metode Weighted Moving Average digunakan karena dengan nilai MAPE IHSG 2019 sebesar 0.844287 nilai MAPE IHSG 2020 sebesar 3.489167 yang lebih kecil dari metode Simple Moving Average. Serta hasil dari perbandingan dampak IHSG dari sebelum terjadi pandemi dengan data dimana sedang terjadi pandemi sangat berpengaruh dan IHSG menurun saat dinyatakan Indonesia sudah terinfeksi Covid-19.
\end{abstract}

Kata kunci: Saham, Covid-19, Perbandingan Saham, Simple Moving Average, Weighted Moving Average.

\section{ABSTRACT}

Stock is a capital market instrument that can be defined as a sign of individual or unilateral capital participation (business entity) in a company or limited liability company. The current factor in the stock market sector is the impact of the corona virus on the stock price index and the flow of foreign funds to the stock market. So it is very necessary to conduct an analysis of the impact of the corona pandemic virus on the stock market sector to see how the JCI movement in Indonesia compares before the pandemic and during the Covid19 pandemic. The method used for comparative analysis is the Simple Moving Average and the Weighted Moving Average. From the results of descriptive analysis on the JCI data in Indonesia, the average Adj Close variable before the pandemic occurred was 6353.71, with a minimum value of 5907.12 and a maximum value of 6525.36. The average value during the pandemic was 5143,929, with a minimum value of 3937,632 and a maximum value of 6325,406. The comparison results show that the Weighted Moving Average method is used because with the 2019 IHSG MAPE value of 0.844287 the 2020 IHSG MAPE value is 3.489167 which is smaller than the Simple Moving Average method. As well as the results of the comparison of the impact of the JCI from before the pandemic occurred with data where the pandemic was occurring was very influential and the JCI decreased when it was declared that Indonesia was infected with Covid-19. 
Keywords: Stock, Covid-19, Stock Comparison, Simple Moving Average, Weighted Moving Average.

\section{PENDAHULUAN}

Coronavirus adalah suatu kelompok virus yang dapat menyebabkan penyakit pada hewan atau manusia. Beberapa jenis coronavirus diketahui menyebabkan infeksi saluran nafas pada manusia mulai dari batuk pilek hingga yang lebih serius seperti Middle East Respiratory Syndrome (MERS) dan Severe Acute Respiratory Syndrome (SARS). Coronavirus jenis baru yang ditemukan menyebabkan penyakit Covid-19. Covid-19 adalah penyakit menular yang disebabkan oleh jenis coronavirus yang baru ditemukan. Ini merupakan virus baru dan penyakit yang sebelumnya tidak dikenal sebelum terjadi wabah di Wuhan, Tiongkok, bulan Desember 2019 [10].

Masyarakat dunia hingga saat ini masih harus terus bertempur melawan pandemik virus corona. Sejumlah negara merasakan adanya peningkatan serta penurunan jumlah kasus yang diakibatkan oleh wabah virus yang mudah menular itu. Berdasarkan data dari Organisasi Kesehatan Dunia (WHO), hingga saat ini tercatat kasus virus corona telah mewabah di 199 kawasan dan negara di dunia, dengan jumlah kasus yang mencapai 465.915 orang, serta telah menyebabkan 21.031 orang meninggal dunia [3].

Berdasarkan laman Data Sebaran Covid-19 [2] (2020) lebih dari 31.000 kasus infeksi Covid-19 yang dilaporkan, Berdasarkan CNN Indonesia [4] (2020) Indonesia juga memiliki kasus virus corona terbanyak kedua di ASEAN. Sementara itu jumlah kasus secara global kini mencapai lebih dari 6,7 juta dan jumlah kematian melewati angka 395.000 pada (07/06). Sebagai negara berkembang, Indonedia dalam sektor perekonomian juga terdampak dengan adanya pandemi Covid-19 dalam sektor pasar saham yang merupakan salah satu jenis surat berharga yang diperdagangkan di bursa efek. Saham diartikan sebagai bukti penyertaan modal di suatu perseroan, atau merupakan bukti kepemilikan atas suatu perusahaan. Siapa saja yang memiliki saham berarti dia ikut menyertakan modal atau memiliki perusahaan yang mengeluarkan saham tersebut. Para pembeli saham membayarkan uang pada perusahaan melalui bursa efek dan mereka menerima sebuah sertifikat saham sebagai tanda bukti kepemilikan mereka atas saham-saham dan kepemilikan mereka dicatat dalam daftar saham perusahaan. Para pemegang saham dari sebuah perusahaan merupakan pemilik-pemilik yang disahkan secara hukum dan berhak untuk mendapatkan bagian dari laba yang diperoleh perusahaan dalam bentuk deviden [6].

Dalam analisis pergerakan harga saham terdapat analisis fundamental dimana mencakup aspek ekonomi, aspek industri, dan aspek perusahaan. Analisis terhadap aspek perusahaan penting untuk dilakukan oleh investor, karena analisis perusahaan ini menyangkut penilaian keadaan keuangan perusahaan, dimana dapat dilihat pendapatan atau laba yang diperoleh perusahaan. Apabila pendapatan atau laba yang diperoleh perusahaan tinggi, hal ini akan dapat membuat harga saham juga tinggi [9].

Faktor yang terjadi sekarang dalam sektor pasar saham yaitu adanya dampak dari virus corona terhadap indeks harga saham dan arus dana asing ke pasar saham. Pasar saham dan nilai tukar ekonomi dipengaruhi oleh beberapa sektor dari dalam negeri yaitu pariwisata, sosial, dan kondisi ekonomi yang banyak memberi kontribusi bagi sektor perekonomian negara. Arus dana yang masuk dari investor asing menjadi lebih variatif karena risk appetite pasar yang menurun disebabkan melemahnya angka indeks saham dalam negeri selama pandemi corona yang memiliki dampak perekonomian.

Pentingnya menganalisis pengaruh dampak virus pandemi corona terhadap sektor pasar saham dan perekonomian membuat acuan dalam beberapa perusahaan dan pemerintahan dalam mengatur arus dana asing supaya angka indeks dan nilai perekonomian tetap stabil. Pergerakan kondisi saham saat belum terjadi pandemi berbeda dengan yang terjadi sekarang. Melihat dari gambaran pergerakan saham tahun lalu sebagai gambaran perbandingan untuk melihat apakah dampak dari Covid-19 ini berpengaruh secara signifikan terhadap IHSG di Indonesia yang sedang menghadapi pandemi covid-19. Penelitian ini juga dilakukan untuk melihat seberapa besar faktor pengaruh dari Covid-19 terhadap IHSG Indonesia. Oleh karena itu, pada penelitian kali ini akan dilakukan analisis data untuk melihat bagaimana perbandingan 
pergerakan IHSG di Indonesia sebelum terjadi pandemi dan pada saat terjadi pandemi Covid19.

\section{Saham}

Saham adalah salah satu instrumen pasar modal yang paling diminati investor karena memberkan tingkat keuntungan yang menarik. Saham dapat didefiniskan sebagai tanda penyetaan modal seorang atau sepihak (badan usaha) dalam suatu perusahaan atau perseroan terbatas. Dengan menyertakan modal tersebut, maka pihak tersebut memiliki klaim atas pendapatan perusahaan, klaim atas aset perusahaan, dan berhak hadir dalam rapat umum pemegang saham. Secara singkat saham dapat dikatakan sebagai bukti tanda kepemilikan duatu perusahaan atau perseroan terbatas. Saham berwujud selembar kertas yang menerbitkan surat berharga tersebut [5].

\section{Moving Average}

Moving average banyak digunakan oleh praktisi, seperti dalam analisis teknis saham ketika akan berjual beli saham. Dalam moving average lebih cepat dalam menentukan pola dan keputusan untuk jual beli saham. Metode ini merupakan salah satu metode peramalan yang cukup simpel dimana melakukan prediksi dengan menggunakan rata-rata seluruh data historis yang dimiliki. Metode ini digunakan ketika tidak terdapat pola trend dan musiman. Karena model ini kurang sesuai untuk menangani data dengan trend atau musiman. Simple moving average yaitu Metode rata-rata bergerak tunggal atau simple moving average merupakan suatu metode peramalan yang dilakukan dengan mengambil sekelompok nilai pengamatan, mencari nilai rata-rata tersebut sebagai ramalan untuk periode yang akan datang. Rata-rata bergerak (moving average) untuk $t$ periode adalah ratarata dari $k$ data terbaru. Nilai konstan $k$ ditentukan di awal ketika melakukan peramalan. Semakin kecil nilai k maka semakin besar bobot yang diberikan pada data terbaru. Sedangkan semakin besar nilai k, maka semakin kecil bobot yang diberikan pada data terbaru. Bobot yang sama diberikan pada setiap data yang digunakan dalam perataan [8]. Weighted moving average adalah metode ini banyak digunakan untuk menentukan tren dari suatu deret waktu, biasanya metode ini digunakan untukdata yang perubahannya tidak cepat. Model rata-rata bergerak menggunakan sejumlah data aktual permintaan yang baru untuk membangkitkan nilai peramalan untuk permintaan di masa yang akan datang. Metode weighted moving average (WMA) merupakan metode yang cocok digunakan pada data yang bersifat time-series dimana data berubah dari waktu ke waktu [7].

\section{Ukuran Akurasi Peramalan}

Ukuran akurasi hasil peramalan atau ukuran kesalahan peramalan merupakan ukuran tentang tingkat perbedaan antara hasil permintaan dengan permintaan yang sebenarnya terjadi. Beberapa metode telah digunakan untuk menunjukkan kesalahan yang disebabkan oleh suatu teknik peramalan tertentu. Hampir semua ukuran tersebut menggunakan pengrata-rataan beberapa fungsi dari perbedaan antara nilai sebenarnya dengan nilai peramalannya. Perbedaan nilai sebenarnya dengan nilai peramalan ini biasanya disebut sebagai residual [1].

\section{METODE}

Data yang digunakan diperoleh dari website Yahoo Finance. Jenis data yang digunakan dalam penelitian ini adalah data sekunder. Data historis akumulasi dari bulan Januari hingga bulan Juni tahun 2019 dan bulan Januari hingga bulan Juni tahun 2020.

Metode yang digunakan pada penelitian ini adalah Metode Simple Moving Average dan Weighted Moving Average. Berikut adalah diagram alur yang akan digunakan didalam penelitian: 


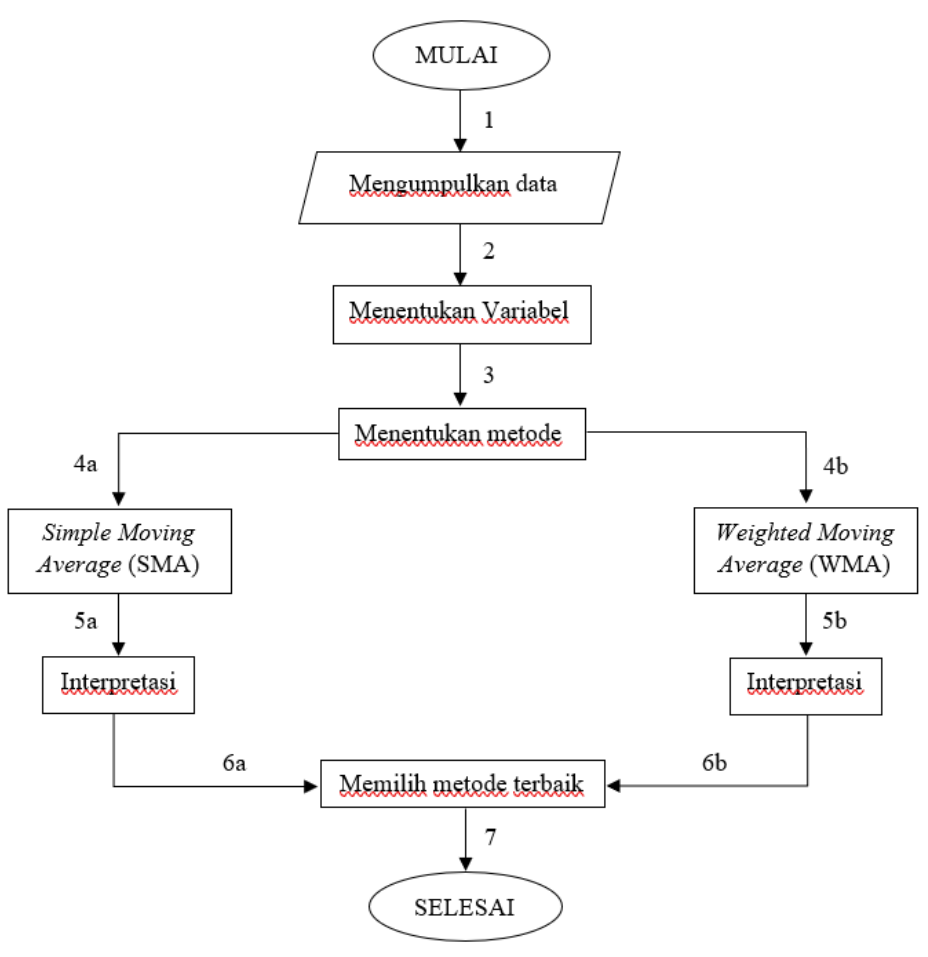

Gambar 1. Flowchart Penelitian.

Penjelasan flowchart:

1. Memulai untuk melakukan penelitian dengan cara mengumpulkan data untuk mengidentifikasi data, mengetahui data yang digunakan seperti apa, dan mengetahui karakteristik data.

2. Setelah mengumpulkan data selanjutnya peneliti menentukan variabel apa saja yang akan digunakan.

3. Setelah mengetahui dan menentukan variabel yang digunakan, selanjutnya menentukan metode yang digunakan yaitu metode Simple Moving Average (SMA) dan Weighted Moving Average (WMA).

4. a. Menggunakan metode Simple Moving Average

b. Menggunakan metode Weighted Moving Average

5. a. Interpretasi grafik dengan membandingkan data saham dengan data hasil perhitungan metode Simple Moving Average.

b. Interpretasi grafik dengan membandingkan data saham dengan data hasil perhitungan metode Weighted Moving Average.

6. Memilih metode terbaik dengan membandingkan nilai tingkat akurasi MSE dan MAPE pada kedua metode, nilai tingkat akurasi yang terkecil adalah metode moving average terbaik.

Secara matematis perhitungan metode Simple Moving Average dapat dirumuskan dalam persamaan sebagai berikut:

$$
F_{t+1}=\hat{y}_{t+1}=\frac{\left(y_{t}+y_{t-1}+y_{t-2}+\cdots+y_{t-k+1}\right)}{k}
$$

dimana:

$F_{t+1}=$ peramalan untuk periode berikutnya

$\hat{y}_{t}=$ data aktual ke-t

$k \quad=$ jumlah periode waktu

Secara matematis perhitungan weighted moving average dapat dirumuskan dalam persamaan berikut:

$F_{t+1}=\frac{k X_{t}+(k-1) X_{t-1}+\cdots+1 X_{t-(n-1)}}{k+(k-1)+\cdots+1}$ 
dimana:

$F_{t+1}=$ peramalan untuk periode berikutnya

$x \quad=$ data aktual ke-t

$k \quad=$ jumlah periode waktu

\section{HASIL DAN PEMBAHASAN}

\section{Indeks Harga Saham Gabungan Indonesia (IHSG)}

IHSG merupakan indeks pergerakan harga saham yang menjadi rujukan perkembangan aktivitas dalam pasar modal serta tercatat dalam Bursa Efek. Data IHSG ini diambil dari penyedia layanan website yahoo yang juga menyediakan berita tentang keuangan termasuk saham. Indeks saham diukur berdasarkan nilai closing price mingguan mulai bulan Januari sampai bulan Juni pada tahun 2019 dan 2020.

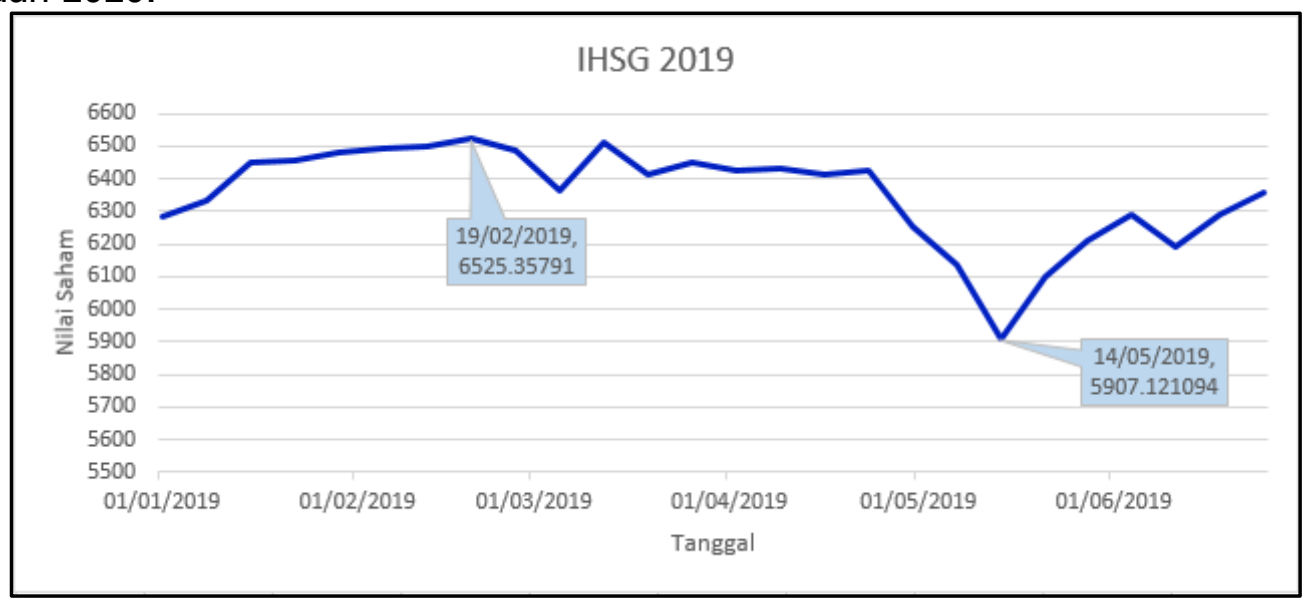

Gambar 2. Grafik Mingguan Data Aktual IHSG 2019.

Grafik pada Gambar 2 menunjukkan grafik data aktual IHSG dari bulan Januari sampai bulan Juni tahun 2019. Data aktual merupakan data asli harga saham yang digunakan, dapat diketahui bahwa perubahan indeks saham dari waktu ke waktu cenderung berfluktuatif. Jumlah indeks saham tertinggi terjadi pada minggu ke empat tanggal 19 Februari dengan angka indeks yang didapatkan sebesar 6525.36. sedangkan pada bulan Mei, terjadi penurunan harga saham yang sangat curam pada penutupan harga saham tepatnya pada minggu ke tiga tanggal 14 Mei 2019 sebesar 5907.12. Akan tetapi, indeks saham mulai naik secara perlahan-lahan pada bulan-bulan berikutnya.

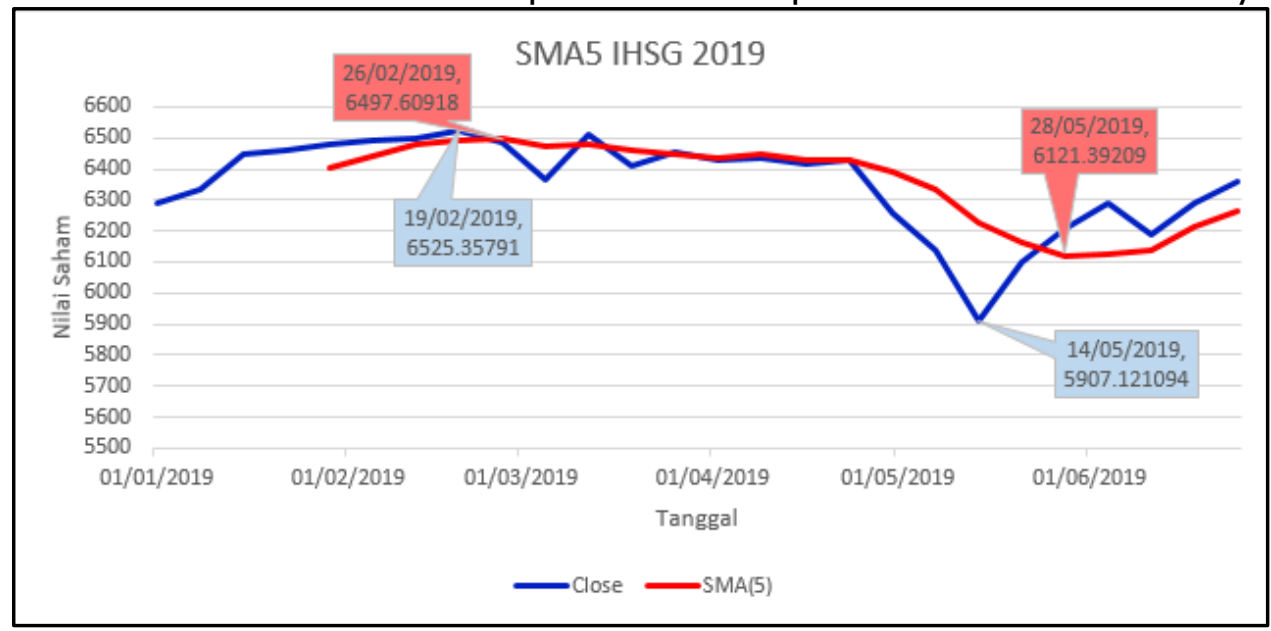

Gambar 3. Grafik Mingguan Data Aktual dan Data Prediksi 2019 Menggunakan Simple Moving Average.

Berdasarkan Gambar 3, garis berwarna biru menunjukkan data aktual mingguan dari IHSG 2019, sedangkan garis berwarna merah merupakan hasil prediksi dari metode SMA dengan panjang periodenya 5 . Setelah dilakukannya prediksi, nilai prediksi diawal periode bulan Februari data saham mengalami kenaikan dimana nilai tertinggi berada pada minggu ke 5 tepatnya tanggal 26 Februari 
dengan nilai indeks yang didapatkan 6497.61 berbeda dari data asli sebelumnya dimana pada data asli nilai tertinggi terdapat pada minggu ke 4. Tetapi di bulan Mei minggu ke 5, harga saham di Indonesia mengalami penurunan yang cukup landai dengan nilai indeks yang didapatkan sebesar 6121.39. Peramalan dengan panjang periode 10 menggunakan metode simple moving average untuk periode ke depannya akan sama dengan hasil periode sebelumnya. Garis berwarna merah pada grafik cenderung bergerak mengikuti data aktual.

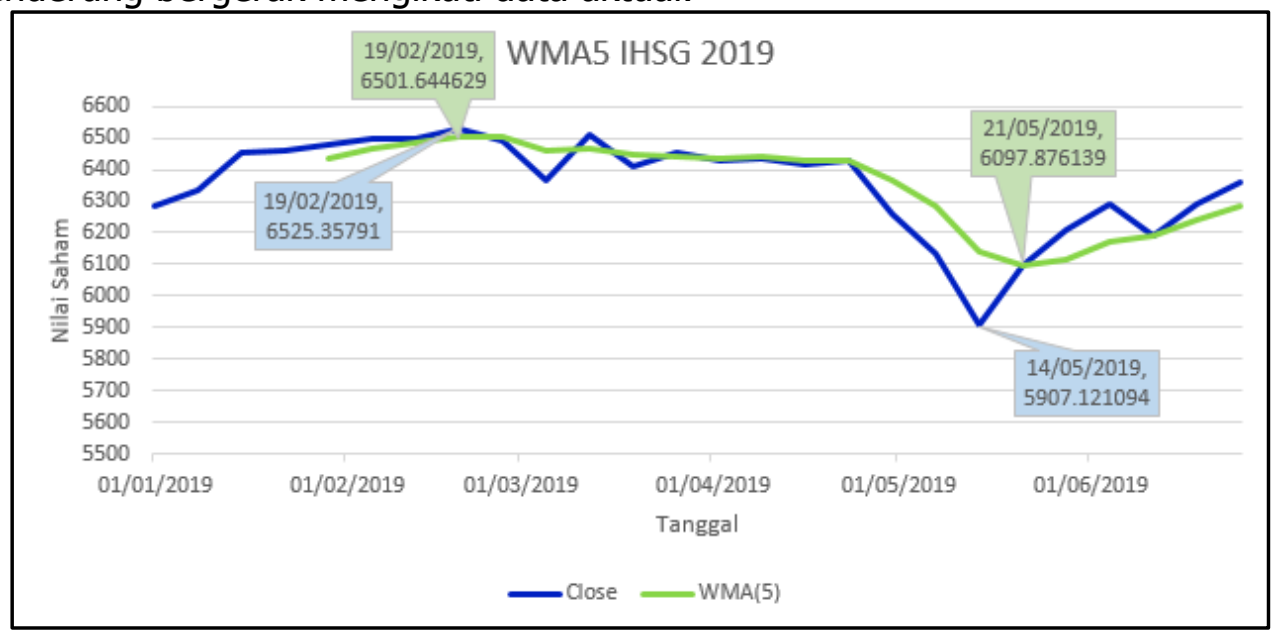

Gambar 4. Grafik Mingguan Data Aktual 2019 dan Data Prediksi Menggunakan Weighted Moving Average.

Berdasarkan Gambar $\mathbf{4}$ hasil prediksi garis berwarna biru menunjukkan data aktual mingguan, sedangkan garis berwarna hijau muda merupakan hasil prediksi dari metode WMA. Metode ini memiliki pembobotan tergantung dari periode yang ditentukan. Semakin besar (baru) periode maka semakin besar pembobotan nilai perhitungannya, panjang periode yang digunakan sebanyak 5 . Setiap titik dalam periode tersebut diberi pengali dimana pengali terbesar untuk titik data terbaru menurun secara berurutan yang mengubah bobot atau signifikansi titik data tertentu tersebut. Dari grafik garis hasil prediksi cenderung bergerak mengikuti data aktualnya, nilai indeks prediksi tertinggi bernilai 6501.64 di minggu ke 4 bulan Februari hampir sama seperti data aktual. Tetapi pada bulan Mei tepatnya minggu ke 4, harga saham mengalami penurunan yang cukup signifikan yaitu angka indeks menunjukkan pada angka 6097.88. Walaupun di bulan Juni harga saham kembali naik tetapi tidak meningkat secara pesat.

Secara visualisasis, setelah dilihat hasil grafik garis masing-masing prediksi menggunakan dua metode yang berbeda yaitu metode SMA dan WMA terhadap data IHSG tahun 2019 saling berdekatan atau dapat dikatakan bahwa nilai prediksi mendekati nilai data aktual IHSG 2019. Berikutnya akan dijelaskan untuk prediksi data IHSG tahun 2020.

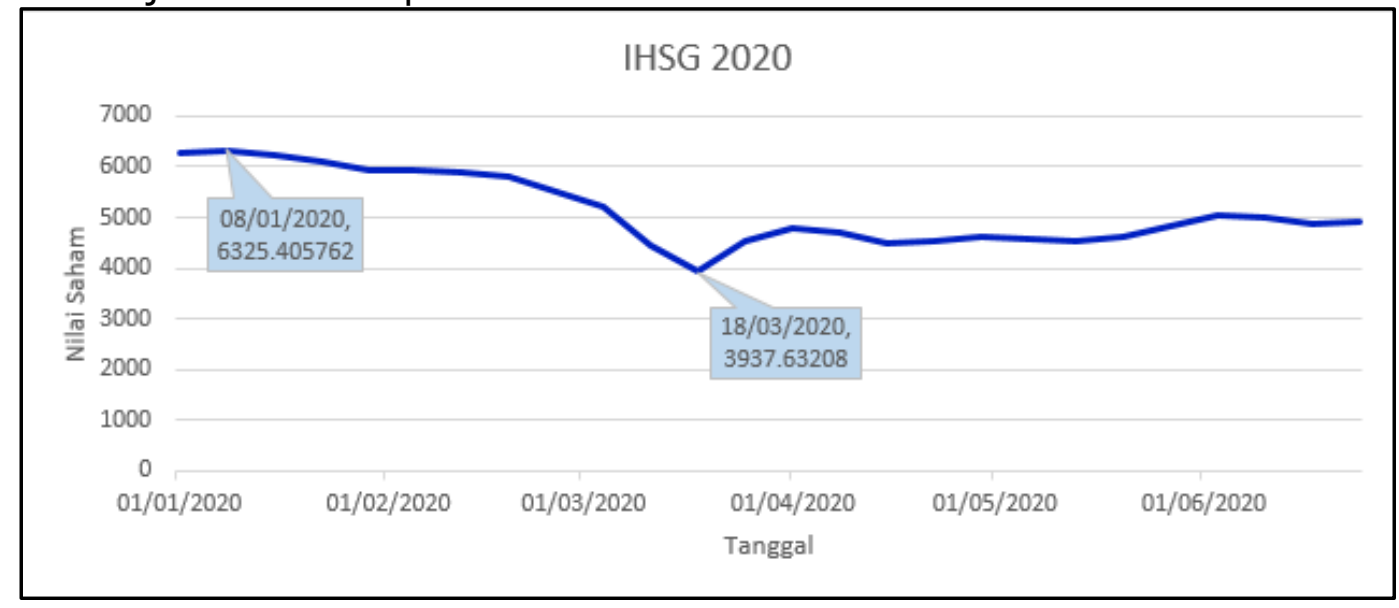

Gambar 5. Grafik Semester Pertama IHSG 2020.

Didapatkan hasil bahwa pada grafik Gambar 5 grafik data IHSG pada bulan Januari sampai bulan Juni 2020. Pada awal periode bulan Januari harga saham mengalami kenaikan yang cukup stabil, dengan nilai indeks sebesar 6325.41 di minggu ke 2 bulan Januari. Di minggu-minggu 
berikutnya harga saham berjalan cukup konstan tidak menunjukkan harga saham menurun. Tetapi di minggu ke 4 bulan Maret, harga saham menurun drastis berbeda pada minggu-minggu sebelumnya angka indeks menunjukkan pada angka 3937,63. Selama 10 minggu terakhir harga saham cukup stabil, walaupun menurun tetapi tidak sangat curam. Lalu dilakukan peramalan untuk 5 periode ke depan menggunakan metode single moving average, dapat dilihat pada gambar selanjutnya.

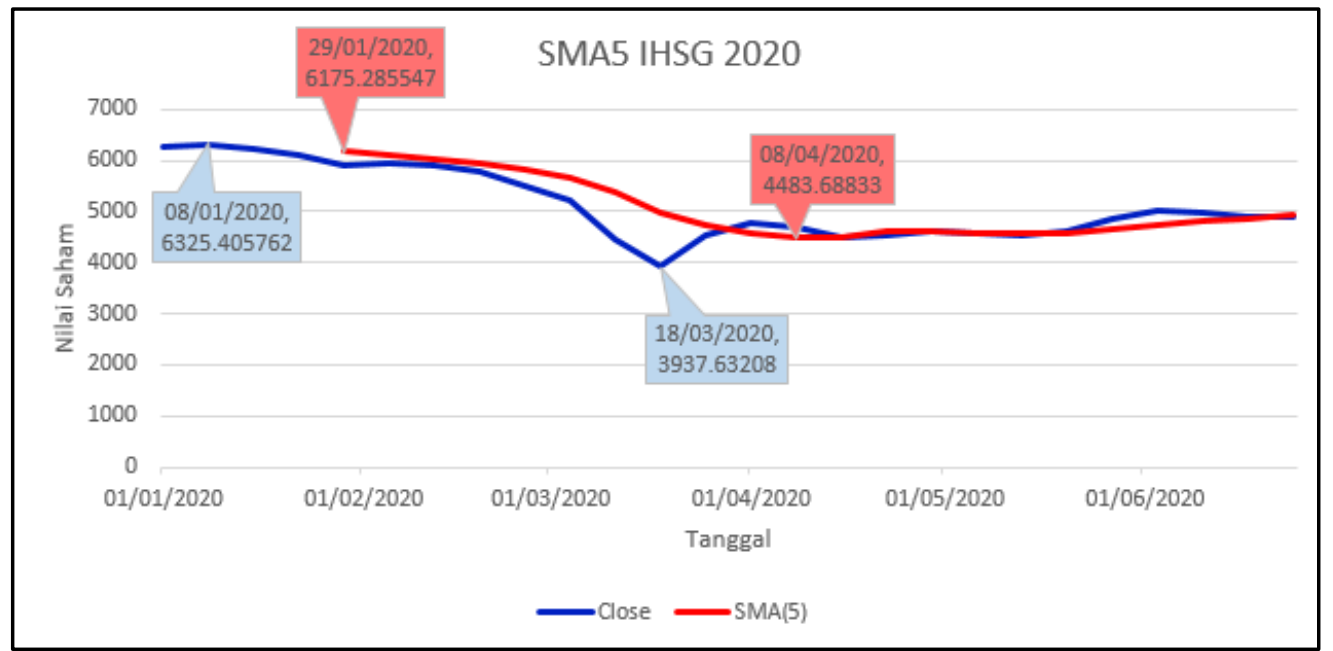

Gambar 6. Grafik Mingguan Data Aktual dan Data Prediksi Menggunakan Simple Moving Average.

Gambar 6 menampilkan grafik mingguan data aktual IHSG tahun 2020 ditandai garis warna biru, sedangkan data prediksi dengan metode WMA berwarna merah. Panjang periode yang digunakan adalah 5. Data hasil prediksi cenderung bergerak mengikuti data sesungguhnya, namun hasil prediksi ini tingkat penuruan harga saham tidak curam seperti data aktualnya. Didapatkan angka indeks hasil prediksi sebesar 4483.69 dimana angka tersebut didapatkan setelah mengalami penuruan pada minggu ke 2 bulan April 2020. Pada minggu berikutnya prediksi memperkirakan bahwa harga saham cukup stabil, tidak mengalami kenaikan dan penuruan. Lalu dilakukan perbandingan prediksi dengan menggunakan metode weighted moving average yang dapat dilihat pada gambar berikutnya.

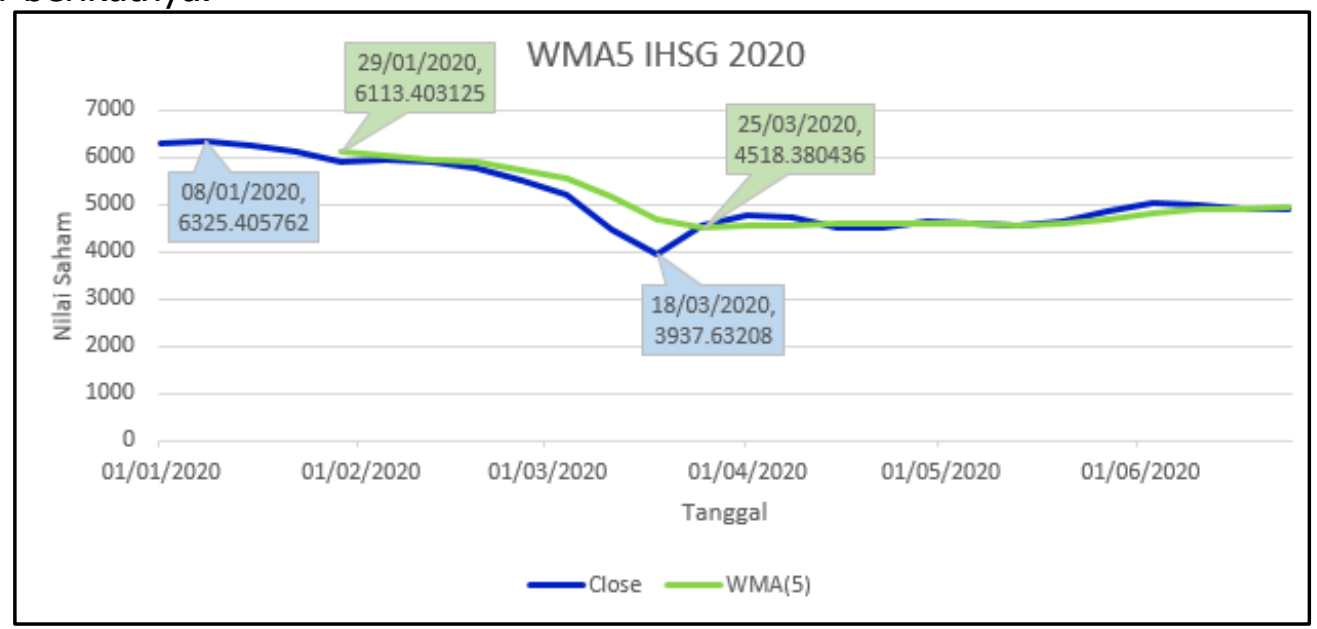

Gambar 7. Grafik Mingguan Data Aktual 2020 dan Data Prediksi Menggunakan Weighted Moving Average.

Sedangkan pada Gambar 7 menunjukkan grafik perbandingan data aktual dengan data prediksi menggunakan metode WMA, panjang periode yang digunakan yaitu 5 . Didapatkan hasil bahwa garis warna biru menunjukkan data aktual mingguan IHSG tahun 2020 dan garis berwarna hijau muda merupakan hasil prediksi dari metode WMA, nilai prediksi tertinggi didapatkan pada akhir periode bulan Januari dengan angka indeks yang menunjukkan sebesar 6113,40 . Seperti yang dikatakan sebelumnya bahwa setiap titik dalam periode yang digunakan akan diberi pengali, masing-masing pengali akan berbeda sesuai dengan pengalinya yaitu pengali terbesar untuk titik data baru dan akan menurun secara berurutan. Sedangkan pada bulan maret minggu ke 4 mengalami penurunan 
cukup fluktuasi, angka indeks harga saham menunjukkan 4518,38 berbeda jauh dengan angka prediksi pada akhir periode bulan Januari.

\section{Nilai MSE dan MAPE}

Nilai MSE dan MAPE digunakan sebagai ukuran akurasi hasil peramalan, dimana mengukur tingkat perbedaan antara hasil permintaan baru dengan permintaan yang sebenarnya terjadi. Nilai MSE (Mean Square Error) sangat penting untuk melihat hasil peramalan yang memiliki nilai kesalahan yang sangat besar. Sedangkan nilai MAPE (Mean Absolute Percentage Error) menyatakan kesalahan hasil peramalan terhadap permintaan aktual selama periode tertentu dengan memberikan informasi kesalahan yang terlalu tinggi atau terlalu rendah, dengan kata lain MAPE merupakan ratarata kesalahan mutlak selama periode tertentu yang kemudian dikalikan $100 \%$ agar mendapatkan hasil secara presentase.

Dari hasil dua metode yang digunakan yaitu SMA dan WMA pada tahun 2019 dan 2020 akan dibandingkan metode manakah yang lebih baik digunakan serta pengaruh manakah yang memberikan efek pada harga saham terhadap Covid-19. Didapatkan nilai Mean Square Error dari terkecil, karena semakin kecil nilai MSE yang didapatkan tingkat keakurasian untuk peramalan semakin baik, dapat dilihat pada tabel berikut:

Tabel 1. Nilai MSE.

\begin{tabular}{ccc}
\hline & IHSG 2019 & IHSG 2020 \\
\hline SMA & 10947,73 & 120702,6 \\
WMA & 6156,778 & 64049,62
\end{tabular}

Pada Tabel 1 hasil MSE terhadap masing-masing metode didapatkan nilai MSE terkecil pada metode WMA yaitu sebesar 6156,778 pada tahun 2019, dan di tahun 2020 metode WMA memiliki nilai jauh lebih kecil dibandingkan hasil nilai SMA yaitu 64049,62. Sedangkan untuk tingkat akurasi dari nilai MAPE dapat dilihat pada Tabel 2.

Tabel 2. Nilai MAPE.

\begin{tabular}{ccc}
\hline & IHSG 2019 & IHSG 2020 \\
\hline SMA & 1,178367 & 4,705661 \\
WMA & 0,844287 & 3,489167
\end{tabular}

Dengan nilai konstan sebesar 5, pada data IHSG mingguan tahun 2019 didapatkan nilai MAPE sebesar 1,178367 dengan menggunakan metode simple moving average sedangkan pada tahun 2020 didapatkan nilai MAPE sebesar 0,84428, dengan menggunakan metode SMA nilai MAPE yang baik berada pada tahun 2019. Tetapi apabila dibandingkan dengan metode WMA nilai-nilai yang didapatkan jauh lebih kecil yaitu 0,844287 tahun 2019 dan 3,489167 tahun 2020. Artinya penggunaan peramalan metode WMA lebih baik untuk digunakan.

Dari kedua nilai akurasi peramalan data IHSG tahun 2019 dan 2020 dengan panjang periode 10, metode WMA lebih baik digunakan untuk perbandingan analisis tren karena kemungkinan terjadinya kesalahan akan lebih sedikit dibandingkan metode SMA.

\section{Perbandingan Tren Harga Saham}




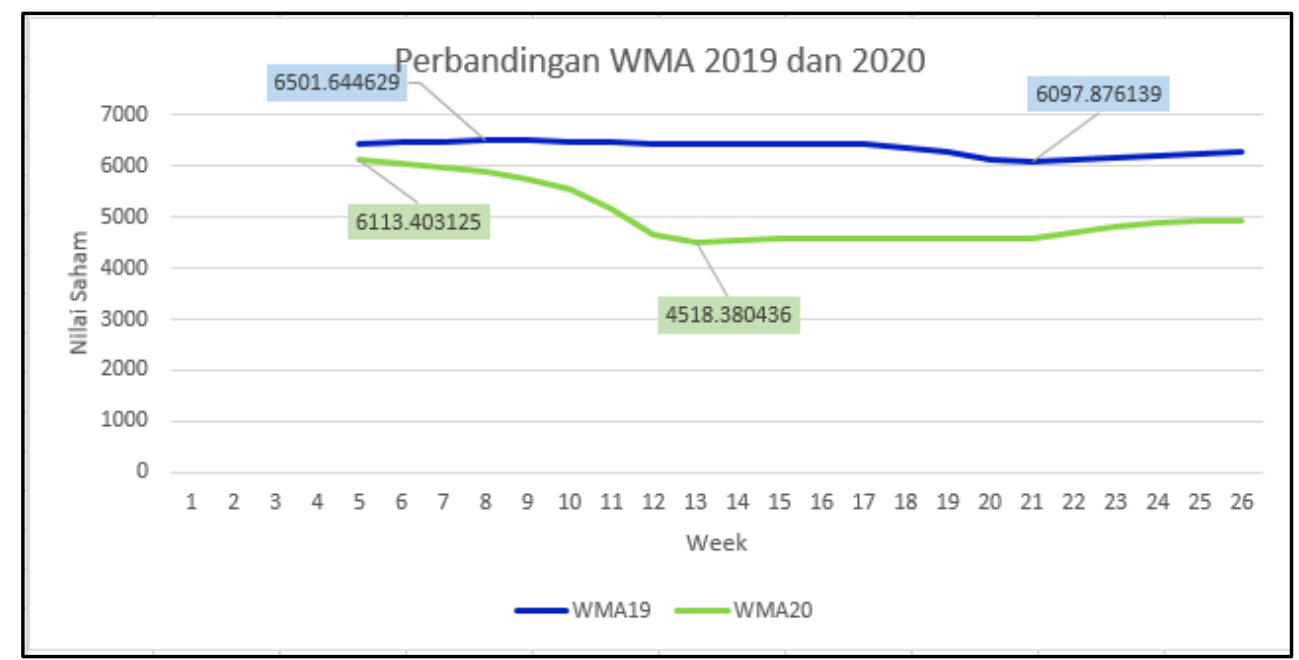

Gambar 8. Grafik Perbandingan Hasil WMA Tahun 2019 dan 2020.

Berdasarkan Gambar 8, hasil perhitungan indeks saham menggunakan WMA antara periode Januari sampai Juni tahun 2019 dan 2020 keduanya mengalami fluktuasi per minggunya. Grafik garis berwarna biru menunjukkan hasil WMA pada data 6 bulan indeks saham tahun 2019, sedangkan perhitungan hasil pada periode Januari sampai Juni tahun 2020 ditunjukkan oleh grafik dengan warna hijau. Kemudian untuk grafik WMA tahun 2020 akhir bulan kedua mengalami penurunan, dan bahkan lebih parahnya lagi pada bulan ketiga saham IHSG di Indonesia turun sangat signifikan jika dibandingkan dengan WMA tahun 2019. Hal ini dipicu dengan diumumkannya bahwa virus Covid-19 di Indonesia sudah menyebar. Dengan kondisi yang berubah secara drastis menyebabkan perekonomian Indonesia cukup kewalahan, namun seriring berjalannya waktu, Indonesia mulai membuat strategi agar perekenomian Indonesia kembali pulih. Presiden RI yaitu bapak Jokowi memberikan usulan agar Indonesia terhindar dari krisis akbiat Covid-19. Salah satunya yaitu menjaga daya beli masyarakat sebagai dampak perlambatan di putaran roda ekonomi, pemerintah diminta untuk dapat mengurangi beban biaya yang secara langsung dalam kendala pemerintah diantaranya seperti tarif dasar listrik, BBM, dan air bersih. Namun kita tidak bisa pungkiri, yang dimana bisa disimpulkan bahwa dengan adanya virus Covid-19 berpengaruh terhadap penurunan saham IHSG di Indonesia pada tahun 2020.

Perbandingan nilai masing-masing periode dari analisis peramalan dengan metode weighted moving average terlihat sekali perbedaannya. Nilai pada periode Januari-Juni 2019 adalah harga rata-rata normal indeks saham Indonesia yang berada di rentang nilai Rp6.000,- hingga Rp6.502,-, kemudian periode Januari-Juni 2020 harga indeks saham di Indonesia menurun cukup drastis hingga Rp4.518,- dari Rp 6.113,- pada 25 Maret 2020. Indeks saham mulai stabil setelah mengalami kenaikan harga dengan rentang nilai Rp4.500,- hingga Rp5.000,- walaupun nilainya masih cukup jauh jauh dibandingkan dengan hasil WMA 6 bulan di tahun 2019. Sebagai ilutrasi, tabel 3 menggambarkan perbandingan hasil WMA per periodenya. Dari hasil perbandingan persentase data saham IHSG tahun 2019 dan 2020 selama awal tahun sampai bulan juni didapatkan nilai dampak penurunan saham sebesar $19,04 \%$ dimana didapat dengan perhitungan seperti pada tabel berikut.

Tabel 3. Perbandingan Dampak Saham Sebelum dan Saat Terjadi Covid-19.

\begin{tabular}{|c|c|c|}
\hline Tahun & $\begin{array}{c}\text { Rata-rata } \\
\text { Saham }\end{array}$ & Persentase \\
\hline 2019 & 6,354 & - \\
\hline 2020 & 5,144 & $-19,04$ \\
\hline
\end{tabular}

\section{KESIMPULAN}

Berdasarkan hasil yang didapatkan dari pembahasan yang sudah dijelaskan pada bagian sebelumnya, maka didapatkan kesimpulan yang pertama yaitu perbandingan saham dari sebelum adanya pandemi Covid-19 (tahun 2019) dan terjadinya penyebaran pandemi Covid-19 (tahun 2020) 
ditandai adanya penurunan grafik perbandingan IHSG di Indonesia dan menunjukkan penurunan harga saham perekonomian di Indonesia. Peramalan dengan metode moving average merupakan metode yang paling sederhana, dan lebih baik jika didapatkan tingkat kesalahan yang lebih kecil. Metode moving average yang digunakan yaitu simple moving average dan weighted moving average. Peramalan dilakukan terhadap data harga saham IHSG Indonesia dalam kurun waktu 6 bulan dari bulan Januari sampai bulan Juni baik tahun 2019 maupun 2020, dengan panjang periode 5. Didapatkan bahwa data harga saham IHSG cenderung fluktatif dalam 6 bulan terakhir. Dari dua metode moving average yang lebih efektif digunakan adalah WMA pada data harga saham IHSG Indonesia, karena memiliki tingkat kesalahan yang lebih kecil. Besar nilai pengaruh dampak saham yang terjadi pandemi dengan sebelum terjadi pandemi sebesar $-19,04 \%$ ditandai dengan penurunan saham perekonomian saat mulai diumumkannya pandemi masuk ke Indonesia.

\section{UCAPAN TERIMA KASIH}

Alhamdulillah, peneliti dapat menyelesaikan makalah penelitian mengenai Pengaruh Covid-19 Terhadap Harga Saham di Indonesia Tahun 2019-2020. Penulis mengucapkan terima kasih kepada:

1. Dr. Edy Widodo, S.Si., M.Si. selaku Ketua Jurusan Statistika dan Dosen Pengampu beserta jajarannya,terima kasih atas limpahan ilmu yang diberikan dari awal hingga akhir serta bimbingan yang tiada hentinya.

2. Shaula Andreinna A, Maulidya Ayu Putri, Umniyyatul Ula, Silva Rizqi Fernanda, Farhatun Nissa, dan Hendro Cahyo Utomo selaku tim penulis laporan statistical consulting.

\section{DAFTAR PUSTAKA}

[1] Arsyad, L. (1997). Peramalan Bisnis. Yogyakarta: BPFE.

[2] COVID-19, G. T. (2020, Juni 07). Data Sebaran COVID-19. Retrieved from Gugus Tugas Percepatan Penanganan COVID-19: https://covid19.go.id/

[3] Dwiantari, I. R. (2020, April 18). Perkembangan COVID-19 di Dunia, Negara Mana Saja yang Terparah?

Retrieved from IDN TIMES: https://www.idntimes.com/news/world/ileny-rizky-

dwiantari/perkembangan-covid-19-di-dunia-negara-mana-saja-yang-terparah/4

[4] Indonesia, C. (2020, Juni 06). Corona Tembus 30 Ribu, Indonesia Urutan ke-2 di Asean. Retrieved from CNN Indonesia: https://www.cnnindonesia.com/nasional/20200606124855-20-510461/coronatembus-30-ribu-indonesia-urutan-ke-2-di-asean

[5] Kurnia, N. (2015). Pengertian Saham.

[6] Nur Komalasari, d. (2017). Academia.edu. Retrieved from Makalah Saham: https://www.academia.edu/35554705/Makalah_saham

[7] Palmitraazzah, A., Slamin, S., \& Juwita, O. (n.d.). Sistem Perencanaan dan Peramalan Distribusi Produk Berdasarkan Jumlah Permintaan Menggunakan Metode Moving Average.

[8] Primandari, A. H. (2017). Course 2 Moving Average. Retrieved from arumprimandari wordpress.com: https://arumprimandari.wordpress.com/subjects/time-series-analysis-2017/

[9] Tanjong, M. (2016, Desember 19). Makalah Alur dan Proses Pembelian Saham. Retrieved from mustafatanjong.blogspot.com: https://mustafatanjong.blogspot.com/2016/12/makalah-alur-danproses-pembelian-saham.html 
Seminar Nasional Official Statistics 2020: Pemodelan Statistika tentang Covid-19

[10] WHO. (2020, April 18). Pertanyaan dan jawaban terkait Coronavirus. Retrieved from World Health Organization South-East Asia Indonesia: https://www.who.int/indonesia/news/novel-coronavirus/qafor-public 